\title{
MENILAI TINGKAT KESEHATAN BANK DENGAN ANALISIS METODE RISK PROFILE, GOOD CORPORATE GOVERNANCE, EARNINGS, CAPITAL PADA BANK SYARIAH DI INDONESIA
}

\author{
Hendra Galuh Febrianto \\ Fakultas Ekonomi Dan Bisnis Universitas Muhammadiyah Tangerang \\ Email: hgf.4646@gmail.com \\ Amalia Indah Fitriana \\ Fakultas Ekonomi Dan Bisnis Universitas Muhammadiyah Tangerang \\ Email: amalia.indahfitriana@gmail.com
}

\begin{abstract}
In the banking world of soundness, banks are very important for the formation of trust. Trust and loyalty to banks is a very helpful factor and makes it easier for bank management to develop good business strategies. Bank Soundness Levels are results issued by banks which are carried out on bank risk and performance (Bank Indonesia Regulation Number: 13/1 / PBI / 2011). If more than conventional banking with Islamic banking, conventional banking finance is better than Islamic banking. This is blessed with poor sharia banking (corporate governance) management. In order to be able to carry out its functions properly, banks must have sufficient capital, ensure the quality of their assets properly, be well managed and managed based on the principle of prudence, generate sufficient profits to maintain an increase, and support liquidity so that it can be adjusted to their needs. Therefore banks are required to be able to achieve and maintain a good and optimal level of performance, because the level of bank performance can increase the level of trust and loyalty needed by the wider community to use the products, services and financial activities of the bank. The purpose of this study is for advanced financial research with analysis of Risk Profiles (Risk Profiles), Good Corporate Governance (GCG), Profitability (Income), and Capital (Capital) which is hereinafter abbreviated as RGEC with the final aim of research for the needs of Sharia banking management in accordance with the latest Bank Indonesia and OJK regulations. This type of research uses descriptive research proposed in the RGEC analysis (Risk Profile, Good Corporate Governance, Income, and Capital) at Islamic Banks in Indonesia. from 2013 to 2017.
\end{abstract}

Keywords: Risk Profile, Good Corporate Governance, Income, Capital, Bank Soundness

\begin{abstract}
Abstrak
Dalam dunia perbankan tingkat kesehatan bank sangat penting bagi pembentukan kepercayaan. Kepercayaan dan loyalitas nasabah terhadap bank merupakan faktor yang sangat membantu dan mempermudah pihak manajemen bank untuk menyusun strategi bisnis yang baik. Tingkat Kesehatan Bank adalah hasil penilaian kondisi bank yang dilakukan terhadap risiko dan kinerja bank (Peraturan Bank Indonesia Nomor: 13/1/PBI/2011). Jika dibanding antara perbankan konvensional dengan perbankan syariah, kinerja keuangan perbankan konvensional lebih baik daripada perbankan syariah. Hal ini dikarena tatakelola (good corporate governance) perbankan




\section{Hendra Galuh P, Amalia Indah F, MENILAI TiNGKat KESEHATAN BANK DeNGAN.............}

syariah yang masih buruk. Agar dapat menjalankan fungsinya dengan baik, bank harus mempunyai modal yang cukup, menjaga kualitas asetnya dengan baik, dikelola dengan baik dan dioperasikan berdasarkan prinsip kehati-hatian, menghasilkan keuntungan yang cukup untuk mempertahankan kelangsungan usahanya, serta memelihara likuiditasnya sehingga dapat memenuhi kewajibannya. Oleh karena itu bank dituntut untuk bisa mencapai dan mempertahankan tingkat kinerja yang baik dan optimal, karena tingkat kinerja bank yang baik dapat meningkatkan kepercayaan dan loyalitas nasabah maupun masyarakat luas untuk menggunakan produk, jasa dan aktivitas keuangan dari bank tersebut. Tujuan penelitian ini adalah untuk menilai tingkat kesehatan keuangan dengan analisis Profil Risiko (Risk Profile), Good Corporate Governance (GCG), Rentabilitas (Earnings), dan Permodalan (Capital) yang selanjutnya disingkat RGEC dengan tujuan akhir merekomendasikan kebijakan untuk memperbaiki manajemen perbankan Syariah yang sesuai peraturan Bank Indonesia dan OJK yang terbaru. Jenis penelitian ini menggunakan penelitian deskriptif yang berfokus pada analisis RGEC (Risk Profile, Good Corporate Governance, Earnings, and Capital) pada Bank Syariah di Indonesia. dari tahun 2013 sampai 2017.

Kata Kunci: Risk Profile, Good Corporate Governance, Earnings, Capital, Tingkat Kesehatan Bank

\section{Dasar Pemikiran}

Perkembangan industri perbankan yang semakin membaik, bank wajib melakukan penilaian tingkat kesehatan bank umum yang sebelumnya menggunakan sistem penilaian yang di atur dalam Peraturan Bank Indonesia Nomor 6/10/PBI/2004 yang dikenal dengan metode CAMELS yaitu terdiri dari Capital, Asset quality, Management, Earnings, Liquidity \& Sensitivity to Market Risk, seiring perkembangan usaha dan kompleksitas usaha bank membuat penggunaan metode CAMELS kurang efektif dalam menilai kinerja bank karena metode CAMELS tidak memberikan suatu kesimpulan yang mengarahkan ke satu penilaian, antar faktor memberikan penilaian yang sifatnya berbeda.

Pada tanggal 25 Oktober 2011 Bank Indonesia sebagai bank sentral menerbitkan peraturan baru mengenai penilaian tingkat kesehatan dengan menggunakan pendekatan risiko (Risk-Based Bank Rating) yang meliputi empat faktor pengukuran, yaitu Profil Risiko (Risk Profile), Good Corporate Governance (GCG), Rentabilitas (Earnings), dan Permodalan (Capital) yang selanjutnya disingkat dengan RGEC. RGEC sebagai metode penilaian kesehatan bank yang dasarnya merujuk pada peraturan Bank Indonesia no. 13/1/PBI/2011 tentang penilaian kesehatan bank umum. Metode RGEC menggantikan CAMELS sebagai tata cara penilaian bank sebelumnya. 
Menurut catatan Biro Riset Infobank, kinerja perbankan syariah tak kunjung membaik sejak 2012. Kejatuhan harga komoditas dan mineral juga menyebabkan perbankan syariah harus bergelut dengan pembiayaan bermasalah. Kinerja yang buruk ini dikarenakan governance atau tata kelola di bank syariah masih harus terus ditingkatkan, selain keandalan SDM syariah yang sering menjadi soal (http://infobanknews.com).

Tingkat Kesehatan Bank adalah hasil penilaian kondisi bank yang dilakukan terhadap risiko dan kinerja bank (Peraturan Bank Indonesia Nomor: 13/1/PBI/2011). Supaya fungsinya dapat berjalan dengan baik, bank harus mempunyai modal yang cukup, menjaga kualitas asetnya dengan baik, dikelola dengan baik dan dioperasikan berdasarkan prinsip kehatihatian, menghasilkan keuntungan yang cukup agar dapat mempertahankan kelangsungan usahanya, serta memelihara likuiditasnya sehingga dapat memenuhi kewajibannya. Berdasarkan fenomena diatas, peneliti mencoba untuk menguji dan menganalisis dengan judul "Menilai Tingkat Kesehatan Bank Dengan Analisis Metode Risk Profile, Good Corporate Governance, Earnings, Capital Pada Bank Syariah Di Indonesia”.

\section{Rumusan Masalah}

Rumusan masalah yang dibangun adalah: 1) Bagaimana Tingkat Kesehatan Bank pada bank Syariah di Indonesia ditinjau dari aspek Risk Profile pada tahun 2013-2017? 2) Bagaimana Tingkat Kesehatan Bank pada bank Syariah di Indonesia ditinjau dari aspek Good Corporate Governance pada tahun 2013-2017? 3) Bagaimana Tingkat Kesehatan Bank pada bank Syariah di Indonesia ditinjau dari aspek Earnings pada tahun 2013-2017? 4) Bagaimana Tingkat Kesehatan Bank pada bank Syariah di Indonesia ditinjau dari aspek Capital pada tahun 2013-2017? 5) Bagaimana Tingkat Kesehatan Bank pada bank Syariah di Indonesia ditinjau dari aspek RGEC pada tahun 2013-2017? 


\section{Hendra Galuh P, Amalia Indah F, MENILAI TINGKAT KESEHATAN BANK DeNGAN.............}

\section{Tujuan Penelitian}

Tujuan dalam penelitian ini yaitu untuk mengetahui: 1) Tingkat Kesehatan Bank pada bank Syariah di Indonesia ditinjau dari aspek Risk Profile tahun 2013-2017? 2) Tingkat Kesehatan Bank pada bank Syariah di Indonesia ditinjau dari aspek Good Corporate Governance tahun 2013-2017? 3)Tingkat Kesehatan Bank pada bank Syariah di Indonesia ditinjau dari aspek Earnings tahun 2013-2017? 4)Tingkat Kesehatan Bank pada bank Syariah di Indonesia ditinjau dari aspek Capital tahun 2013-2017? 5)Tingkat Kesehatan Bank pada bank Syariah di Indonesia ditinjau dari aspek RGEC tahun 2013$2017 ?$

\section{Tinjauan Pustaka}

\section{Laporan Keuangan}

Menurut Fahmi Laporan keuangan adalah suatu informasi yang menggambarkan kondisi keuangan, dan lebih jauh informasi tersebut dapat dijadikan sebagai gambaran kinerja keuangan suatu perusahaan tersebut (Fahmi, 2014). Sedangkan menurut Kasmir, Laporan keuangan di samping menggambarkan kondisi keuangan suatu bank juga untuk menilai kinerja manajemen bank yang bersangkutan (Kasmir, 2014a, p. 281). Penilaian kinerja manajemen akan menjadi patokan apakah manajemen berhasil atau tidak dalam menjalankan kebijakan yang telah digariskan oleh perusahaan.

Menurut (Veithzal, 2007, p. 616), Tujuan dari laporan keuangan adalah sebagai berikut:

a. Memberikan informasi kas yang dapat dipercaya mengenai posisi keuangan (perusahaan/bank) pada suatu saat tertentu.

b. Memberikan informasi keuangan yang dapat dipercaya mengenai hasil perusahaan/bank selama periode tertentu.

c. Memberikan informasi yang dapat membantu pihak-pihak yang berkepentingan untuk menilai atau mengintepretasikan kondisi dan potensi suatu perusahaan/bank.

d. Memberikan informasi penting lainnya yang releven sesuai kebutuhan pihakpihak yang berkepentingan dengan laporan kebutuhan yang bersangkutan. 


\section{Bank}

Menurut Kasmir bank dikenal sebagai lembaga keuangan yang kegiatan utamanya menerima simpanan giro, tabungan dan deposito. Bank juga dikenal sebagai tempat untuk menukar uang, memindahkan uang atau menerima segala bentuk pembayaran dan setoran seperti pembayaran listrik, telepon, air pajak, uang kuliah dan pembayaran lainnya (Kasmir, 2014b, p. 25). Secara umum fungsi utama dari bank adalah menghimpun dana dari masyarakat dan menyalurkan kembali kepada masyarakat untuk berbagai tujuan atau sebagai Financial Intermediary. Undang-Undang (UU) Nomor 21 tahun 2008 tentang perbankan syariah menyatakan bahwa perbankan syariah melakukan kegiatan usahanya berdasarkan prinsip syariah, demokrasi ekonomi, dan prinsip kehatihatian (Aravik, 2020). Perbankan syariah bertujuan menunjang pelaksanaan pembangunan nasional dalam rangka meningkatkan keadilan, kebersamaan, dan pemerataan kesejahteraan rakyat. Menurut Fitriana (Fitriana et al., 2015) secara spesifik bank dapat berfungsi sebagai :

a. Agent of Trust

Dasar utama kegiatan perbankan adalah kepercayaan. Masyarakat akan mau menitipkan dananya di bank karena adanya kepercayaan. Pihak bank juga akan menyalurkan dananya kepada debitur karena adanya unsur kepercayaan.

\section{b. Agent of Development}

Kegiatan bank yang berupa menghimpun dan menyalurkan dana memungkinkan masyarakat melakukan kegiatan investasi, kegiatan distribusi, serta kegiatan konsumsi barang dan jasa. Kelancaran kegiatan investasi-distribusi-konsumsi adalah kegiatan pembangunan perekonomian suatu masyarakat.

c. Agent of Services

Bank memberikan penawaran jasa perbankan lain, seperti jasa pengiriman uang, penitipan barang berharga, pemberian jaminan bank, dan penyelesaian tagihan. 


\section{4 | Hendra Galuh P, Amalia Indah F, MENILAI TINGKat KESEHATAN BANK DeNGAN.............}

\section{Tingkat Kesehatan Bank RGEC}

\section{a. Risk Profile (Profil Risiko)}

Penilaian risiko merupakan penilaian atas risiko yang melekat pada kegiatan bisnis bank, baik yang dapat dikuantifikasikan maupun yang tidak, yang berptensi mempengaruhi posisi keuangan bank. Penilaian kualitas penerapan manajemen risiko merupakan penilaian terhadap aspek: (a) tata kelola risiko, (b) kerangka manajemen risiko, (c) proses manajemen risiko, kecukupan sumber daya manusia, dan kecukupan sistem informasi manajemen, serta kecukupan sistem pengendalian risiko dengan memperhatikan karakteristik dan kompleksitas usaha bank (SOJK Nomor. 10/POJK.03/2014).

\section{b. Good Corporate Governance (GCG)}

Pengertian GCG menurut PBI Nomor 11/33/PBI/2009 tentang pelaksanaan GCG bagi BUS dan/atau UUS adalah suatu tata kelola bank yang menerapkan prinsip-prinsip transparansi (tranparancy), akuntabilitas (accountability), pertanggungjawaban (responsibility), profesional (profesional), dan kewajaran (fairness).

\section{c. Earning (Rentabilitas)}

Menurut Haris (Haris \& Hastuti, 2013), penilaian rentabilitas merupakan penilaian terhadap kondisi dan kemampuan bank untuk menghasilkan keunungan dalam rangka mendukung kegiatan operasional dan permodalan.

\section{d. Capital (Permodalan)}

Menurut Rahmaniah dan Wibowo (Rahmaniah \& Wibowo, 2015), permodalan bagi bank sebagaimana perusahaan pada umumnya selain berfungsi sebagai sumber utama pembiayaan terhadap kegiatan operasionalnya juga berperan sebagai penyangga terhadap kemungkinan terjadinya kerugian. Selain itu, modal juga berfungsi menjaga kepercayaan masyarakat terhadap kemampuan bank dalam menjalankan fungsinya sebagai lembaga intermediasi.

\section{Kerangka Penelitian}

Penelitian ini dilakukan untuk menilai tingkat kesehatan bank berdasarkan Peraturan Bank Indonesia penilaian kesehatan Bank Umum ditentukan dalam Surat 
Edaran No. 13/24/DPNP tanggal 25 Oktober 2011 menyatakan bahwa penilaian tingkat kesehatan bank dinilai dengan analisis RGEC yang terdiri dari: Risiko (risk profile), Good Corporate Governance, Earning, dan Capital. Sebagai ilustrasi dari penjelasan di atas dapat digambarkan dalam gambar sebagai berikut:

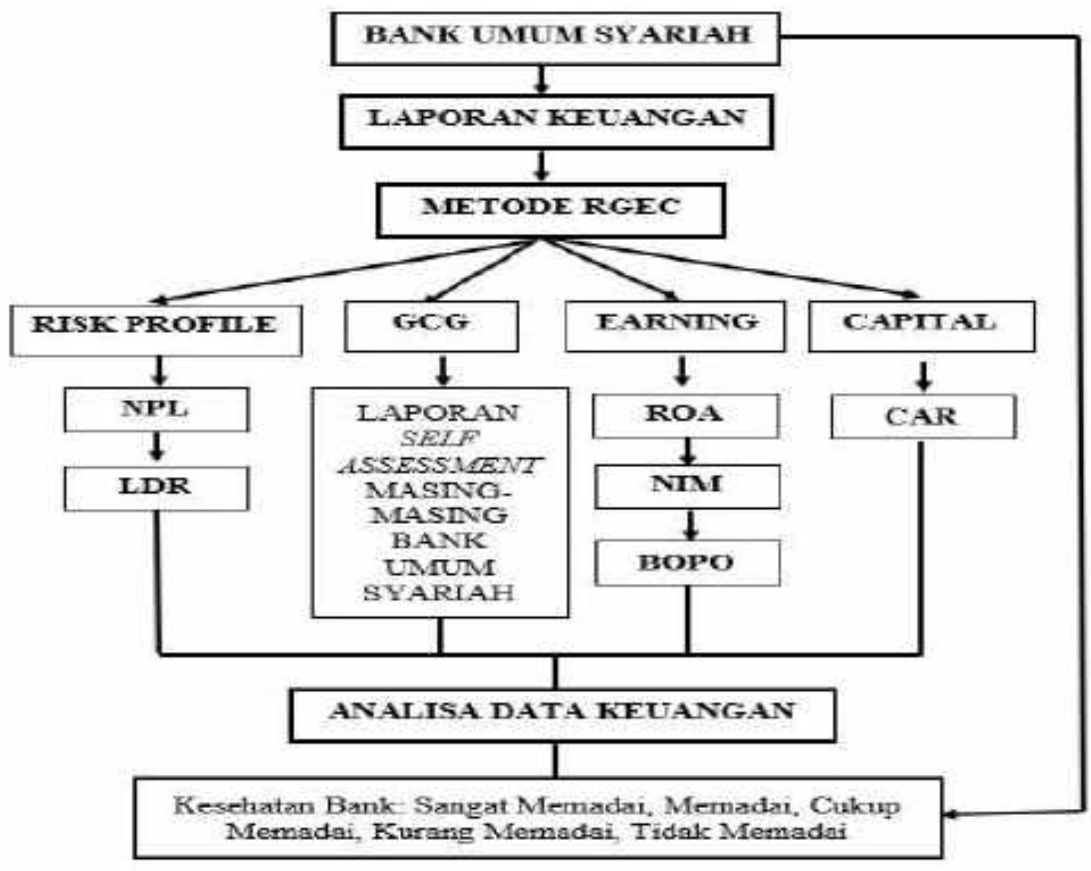

\section{Metode Penelitian}

\section{Populasi, Sampel, Teknik Pengambilan Sampel}

Populasi dalam penelitian ini yaitu Bursa Efek Indonesia ( IDX ). Sampel dalam penelitian ini yaitu Bank Umum Syariah di Indonesia pada tahun 2013 - 2017. Bank umum syariah yang terdaftar pada situs Bank Indonesia adalah:

1) PT Bank Syariah Mandiri

2) PT Bank Syariah Muamalat Indonesia

3) PT Bank Syariah BNI

4) PT Bank Syariah BRI

5) PT Bank Syariah Mega Indonesia

6) PT Bank Jabar dan Banten Syariah

7) PT Bank Panin Syariah 


\section{Hendra Galuh P, Amalia Indah F, MENILAI TINGKAT KESEHATAN BANK DENGAN.............}

8) PT Bank Syariah Bukopin

9) PT Bank Victoria Syariah

10) PT Bank BCA Syariah

11) PT Bank Tabungan Pensiun nasional Syariah

12) PT Bank Aceh Syariah

13) PT Bank BPD Nusa Tenggara Barat Syariah dan

14) PT Maybank Indonesia Syariah.

Metode pengambilan sampel yang digunakan dalam penelitian ini adalah metode purposive sampling.

Kriteria - kriteria yang digunakan dalam pengambilan sampel ini sbb:

a. Bank yang secara rutin menyajikan data lengkap dan mempublikasikan laporan keuangan dan laporan Good Corporate Governance secara berurutan selama 2013 2017.

b. Perusahaan tersebut memiliki laporan keuangan auditan tiap tahunnya.

Data yang digunakan dalam penelitian ini adalah data sekunder atau data dokumenter. Data dalam penelitian ini menggunakan data laporan-laporan keuangan yang sudah go public yang terdaftar di Bursa Efek Indonesia (BEI).

\section{Operasionalisasi Variabel}

Tabel 1 Operasionalisasi Variabel

\begin{tabular}{|c|c|c|c|}
\hline No: & Variabel & Definisi Variabel & Pengukuran \\
\hline \multirow[t]{2}{*}{1} & \multirow[t]{2}{*}{$\begin{array}{l}\text { Risk Profle } \\
\text { (Profile Risiko) }\end{array}$} & \multirow{2}{*}{$\begin{array}{l}\text { Risk profile adalah penilaian melalui } \\
\text { rusiko inheren dan kualitas penerapan } \\
\text { manajemen risiko dalam operasional } \\
\text { bank yang terdixi dari delapan riaike. }\end{array}$} & NPL $=\frac{\text { Kredit Bermasatah }}{\text { Total Kredit }} \times 100 \%$ \\
\hline & & & LDR - $\frac{\text { Iumlah Kredit Yang Diberikan }}{\text { Dana Pihak Kotiga }} \times 100 \%$ \\
\hline 2 & $\begin{array}{l}\text { Good } \\
\text { Corporate } \\
\text { Govenance } \\
(\text { GCG) }\end{array}$ & 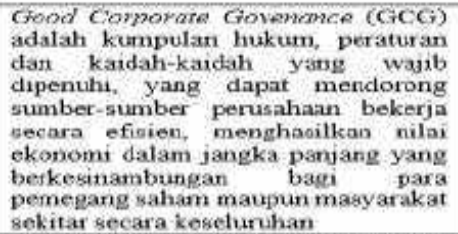 & $\begin{array}{l}\text { Analisis Ciosd Corporote Governance } \\
\text { dikelompokkan dalam suatu govomance system yani } \\
\text { terdiri dari } 3 \text { (tiga) aspek governance, yaitu } \\
\text { govemance structure, governance procesess, dan } \\
\text { governance outcome. }\end{array}$ \\
\hline \multirow[t]{3}{*}{3} & \multirow[t]{3}{*}{$\begin{array}{l}\text { Earnirgs } \\
\text { (Rentabilitas) }\end{array}$} & \multirow{3}{*}{$\begin{array}{l}\text { Rentabilitas adalain pengukuran yang } \\
\text { digunakan untuk mengukur } \\
\text { kompetensi bank dalam } \\
\text { meningkatkan pendapatannya dalam } \\
\text { periode yang tolah ditentukan. }\end{array}$} & ROA $=\frac{\text { Labasebelum Pajak }}{\text { Rata-Rata total Aset }} \times 100 \%$ \\
\hline & & & NIM $-\frac{\text { Pendapatan Bungsa Bersith }}{\text { Rata Rata Aktiva Produktif }} \times 100 \%$ \\
\hline & & & BOPO $-\frac{\text { Beban operastomal }}{\text { Pendapatan aperasional }} \times 100 \%$ \\
\hline 4 & $\begin{array}{l}\text { Cipinal } \\
\text { (Permodalan) }\end{array}$ & $\begin{array}{l}\text { Permodalan merupakan daria yang } \\
\text { dimvestasikan oleh pemilik pada } \\
\text { wadctu pendirian bank vang dimakiud } \\
\text { untuk membiayai kegiatan usaha } \\
\text { bank. }\end{array}$ & $C A R=\frac{M \text { octal }}{A T M R} \times 100 \%$ \\
\hline
\end{tabular}


ISLAMIC BANKING: Jurnal Pemikiran dan Pengembangan Perbankan Syariah, Volume 6 Nomor 1 Edisi Agustus 2020

\section{Metode Analisis}

Dalam penelitian ini memakai penelitian deskriptif yang berfokus pada analisis RGEC (Risk Profile, Good Corporate Governance, Earnings, and Capital). Langkahlangkah analisis dari penelitian ini sebagai berikut:

1. Menghitung rasio Risk Profile yang terdiri dari Risiko Kredit (NPL) dan Risiko Likuiditas (LDR).

2. Menganalisis nilai self assesment Good Corporate Governance.

3. Menghitung rasio Earning yang terdiri dari ROA, ROE, dan BOPO.

4. Menghitung rasio Capital yang menggunakan CAR.

5. Setelah menghitung, kemudian melakukan interpretasi serta pemeringkatan masing-masing analisis NPL, LDR, ROA, NIM, BOPO, dan CAR.

6. Menarik kesimpulan terhadap tingkat kesehatan bank sesuai standar perhitungan kesehatan bank yang telah ditentukan oleh Bank Indonesia berdasarkan pada hasil perhitungan rasio tersebut.

Peringkat Komposit Tingkat Kesehatan Bank ditetapkan berdasarkan analisis secara komprehensif dan terstruktur terhadap peringkat setiap faktor: profil risiko, GCG, rentabilitas, dan permodalan dengan memperhatikan materialitas dan signifikansi masingmasing faktor. Peringkat komposit sebagaimana dimaksud sebagai berikut:

Tabel

\begin{tabular}{|c|c|}
\hline \multicolumn{2}{|c|}{ Peringkat Komposit Perbankan } \\
\hline Peringkat Komposit & Keterangan \\
\hline PK-1 & $\begin{array}{l}\text { Mencerminkan lcondisi Bank secara umtum sangat sehat } \\
\text { sehingga dinilai sangat mampu menghadapi pengaruh } \\
\text { negatif yang signifikan dari perubahan kondisi bisnis dan } \\
\text { faktor ekstemal lainmya. }\end{array}$ \\
\hline PK-2 & $\begin{array}{l}\text { Mencerminkan kondisi Bank yang secara umum sehat } \\
\text { sehingga dinilai mampu menghadapi pengarth negatif } \\
\text { yang signifikan dari perubahan kondisi bisnis dan faktot } \\
\text { eksternal laimrya. }\end{array}$ \\
\hline PK-3 & $\begin{array}{l}\text { Mencerminkan kondisi Bank yang secara umum cukup } \\
\text { sehat sehingga dinilai cukuo mampu menghadapi } \\
\text { pengaruh negatif yang signifikn dari perubahan kondisi } \\
\text { bisnis dan faktor ekternal lainnya. }\end{array}$ \\
\hline PK-4 & $\begin{array}{l}\text { Mencerminkan kondisi Bank yangsecara tmum karang } \\
\text { seluaat sehingga dinilai karang mampu menghadapi } \\
\text { pengarnh negatif yang signifikan dari perubahan kondisi } \\
\text { bisnis dan faktor eksterna lainnya. }\end{array}$ \\
\hline PK-5 & $\begin{array}{l}\text { Meneerminkan kondisi Bank yang secara umum tidak } \\
\text { sehat sehingga dinilai tidak mempu menghadapi } \\
\text { pengaruh negarif yang signifikan dari penubahan kondisi } \\
\text { bismis dan faktor ekstemal lainnya. }\end{array}$ \\
\hline
\end{tabular}

Sumber: SE No.13/24/DPNP/2011 tanggal 25 Oktober 2011 


\section{Hasil Dan Pembahasan}

\section{Penilaian Kesehatan Bank Syariah Dengan Metode RGEC}

Penilaian kesehatan bank dilakukan dengan menilai beberapa faktor yang indikator sehat atau tidaknya suatu bank. Berdasarkan Peraturan Bank Indonesia No. 13/1/PBI/2011 dan SE No. 13/ 24/ DPNP tanggal 25 Oktober 2011 tentang Sistem Penilaian Tingkat Kesehatan Bank Umum. Penilaian kesehatan bank berdasarkan urutan bank adalah sebagai berikut:

1. Bank Syariah Mandiri

Tabel 3

Penilaian Tingkat Kesehatan Bank Syariah Mandiri Periode 2013-2017

\begin{tabular}{|c|l|c|c|c|c|c|}
\hline \multirow{2}{*}{$\begin{array}{c}\text { Komponen } \\
\text { Faktor }\end{array}$} & \multirow{2}{*}{ Rasio } & \multicolumn{5}{|c|}{ \% Rasio } \\
\cline { 2 - 7 } Profil Risiko & NPF & 1,14 & 1,16 & 1,10 & 1,09 & 1,09 \\
\cline { 2 - 7 } & FDR & 78,80 & 78,87 & 80,01 & 81,73 & 81,87 \\
\hline GCG & GCG & 3 & 3 & 3 & 3 & 3 \\
\hline \multirow{3}{*}{ Rentabilitas } & ROA & 1,38 & 0,04 & 0,53 & 0,55 & 1,28 \\
\cline { 2 - 7 } & ROE & 43,72 & 2,96 & 14,53 & 16,34 & 15,45 \\
\cline { 2 - 7 } & BOPO & 67,17 & 74,25 & 68,64 & 66,68 & 65,78 \\
\hline Permodalan & CAR & 12,31 & 12,23 & 11,66 & 12,50 & 12,34 \\
\hline Peringkat Komposit & $\mathbf{1}$ & $\mathbf{2}$ & $\mathbf{2}$ & $\mathbf{2}$ & $\mathbf{2}$ \\
\hline \multicolumn{2}{|c}{ Keterangan } & $\begin{array}{c}\text { Sangat } \\
\text { sehat }\end{array}$ & Sehat & Sehat & Sehat & Sehat \\
\hline
\end{tabular}

Sumber: Data Diolah

Nilai rasio diatas menunjukkan predikat kesehatan Bank Syariah Mandiri pada tahun 2013 dari tujuh komponen yang dihitung, NPF, FDR, GCG, ROA, ROE, BOPO dan CAR hasilnya: 1,$14 ; 78,80 ; 3 ; 1,38 ; 43,72 ; 67,17$ dan 12,31 masuk kedalam komposit 1 yaitu sangat sehat. Pada tahun 2014 nilai rasio, NPF, FDR, GCG, ROA, ROE, BOPO dan CAR hasilnya: 1,16; 78,87; 3; 0,04; 2,96; 74,25 dan 12,23 masuk kedalam komposit 2 yaitu sehat. Tahun 2015 nilai rasio NPF, FDR, GCG, ROA, ROE, BOPO dan CAR sebesar: 1,10; 80,01; 3; 0,53; 14,53; 68,64 dan 11,66 masuk komposit 2 sehat. Tahun 2016, NPF, FDR, GCG, ROA, ROE, BOPO dan CAR nilai rasio sebesar: 1,09; 81,73; 3; 0,55; 16,34; 66,68 dan, 12,50 masuk komposit 2 sehat. Tahun 2017, NPF, FDR, GCG, ROA, ROE, BOPO dan CAR sebesar: 1,09; 81,87; 3; 1,28; 15,45; 65,78 dan 12,34 masuk kategori 2 sehat. Sesuai dengan standar yang telah 
ditetapkan oleh Bank Indonesia, pada tahun 2013-2017 Bank Syariah Mandiri dengan kesimpulan ada di peringkat komposit 2 yaitu sehat yang mencerminkan kondisi bank secara umum yaitu sehat, sehingga dinilai mampu menghadapi pengaruh negatif yang signifikan dari perubahan kondisi bisnis dan juga faktor lainnya.

2. PT Bank Syariah Muamalat Indonesia

Tabel 4

Penilaian Tingkat Kesehatan Bank Syariah Muamalat Indonesia

Periode 2013-2017

\begin{tabular}{|c|l|c|c|c|c|c|}
\hline \multirow{2}{*}{$\begin{array}{c}\text { Komponen } \\
\text { Faktor }\end{array}$} & \multirow{2}{*}{ Rasio } & \multicolumn{5}{|c|}{$\%$ Rasio } \\
\cline { 2 - 7 } & 2013 & 2014 & 2015 & 2016 & 2017 \\
\hline \multirow{2}{*}{ Profil Risiko } & NPF & 1,71 & 4,93 & 8,94 & 4,28 & 4,32 \\
\cline { 2 - 7 } & FDR & 99,99 & 84,14 & 90,30 & 95,13 & 96,45 \\
\hline \multirow{2}{*}{ GCG } & GCG & 4 & 4 & 4 & 4 & 4 \\
\hline \multirow{3}{*}{ Rentabilitas } & ROA & 0,45 & 0,16 & 0,19 & 0,21 & 0,32 \\
\cline { 2 - 7 } & ROE & 14,96 & 5,26 & 6,71 & 7,25 & 8,34 \\
\cline { 2 - 7 } & BOPO & 38,20 & 35,21 & 40,64 & 44,96 & 44,56 \\
\hline Permodalan & CAR & 11,80 & 9,36 & 8,45 & 8,83 & 8,76 \\
\hline Peringkat Komposit & $\mathbf{3}$ & $\mathbf{3}$ & $\mathbf{3}$ & $\mathbf{3}$ & $\mathbf{3}$ \\
\hline \multicolumn{2}{|c|}{ Keterangan } & $\begin{array}{c}\text { Cukup } \\
\text { sehat }\end{array}$ & $\begin{array}{c}\text { Cukup } \\
\text { sehat }\end{array}$ & $\begin{array}{c}\text { Cukup } \\
\text { sehat }\end{array}$ & $\begin{array}{c}\text { Cukup } \\
\text { sehat }\end{array}$ & $\begin{array}{c}\text { Cukup } \\
\text { sehat }\end{array}$ \\
\hline
\end{tabular}

Sumber: Data Diolah

Nilai rasio dari bank muamalat diatas menunjukkan predikat kesehatan tahun 2013 dari tujuh komponen yang dihitung, NPF, FDR, GCG, ROA, ROE, BOPO dan CAR hasilnya: 1,71; 99,99; 4; 0,45; 14,96; 38,20 dan 11,80 masuk kedalam komposit 3 yaitu cukup sehat. Pada tahun 2014 nilai rasio, NPF, FDR, GCG, ROA, ROE, BOPO dan CAR hasilnya: 4,93; 84,14; 4; 0,16; 5,26; 35,21 dan 9,36 masuk kedalam komposit 3 yaitu cukup sehat. Tahun 2015 nilai rasio NPF, FDR, GCG, ROA, ROE, BOPO dan CAR sebesar: 8,94; 90,30; 4; 0,19; 6,71; 40,64 dan 8,45 masuk komposit 3 cukup sehat. Tahun 2016 NPF, FDR, GCG, ROA, ROE, BOPO dan CAR nilai rasio sebesar: 4,28; 95,13; 4; 0,21; 7,25; 44,96 dan 8,83 masuk komposit 3 cukup sehat. Tahun 2017 NPF, FDR, GCG, ROA, ROE, BOPO dan CAR sebesar: 4,32; 96,45; 4; 0,32; 8,34; 44,56 dan 8,76 masuk kategori 3 Cukup sehat. Sesuai dengan standar yang telah ditetapkan oleh Bank Indonesia, pada tahun 2013-2017 Bank Syariah Muamalat Indonesia dengan kesimpulan ada di peringkat komposit 3 yaitu cukup sehat yang mencerminkan kondisi 
150

Hendra Galuh P, Amalia Indah F, MENILAI TINGKAT KESEHATAN BANK DENGAN............

bank secara umum yaitu cukup sehat, sehingga dinilai mampu menghadapi pengaruh negatif yang signifikan dari perubahan kondisi bisnis dan juga faktor lainnya.

3. PT Bank Syariah BNI

Tabel 5

Penilaian Tingkat Kesehatan Bank Syariah BNI Periode 2013-2017

\begin{tabular}{|c|l|c|c|c|c|c|}
\hline \multirow{2}{*}{$\begin{array}{c}\text { Komponen } \\
\text { Faktor }\end{array}$} & \multirow{2}{*}{ Rasio } & \multicolumn{5}{|c|}{$\%$ Rasio } \\
\cline { 2 - 7 } Profil Risiko & 2013 & 2014 & 2015 & 2016 & 2017 \\
& NPF & 1,74 & 2,42 & 1,01 & 1,75 & 1,65 \\
\cline { 2 - 7 } & FDR & 97,86 & 92,60 & 91,94 & 90,84 & 91,02 \\
\hline \multirow{3}{*}{ GCG } & GCG & 3 & 3 & 3 & 3 & 3 \\
\hline \multirow{3}{*}{ Rentabilitas } & ROA & 1,22 & 1,13 & 1,33 & 1,32 & 1,29 \\
\cline { 2 - 7 } & ROE & 11,69 & 10,86 & 15,19 & 18,45 & 18,70 \\
\cline { 2 - 7 } & BOPO & 65,88 & 55,25 & 49,12 & 48,09 & 47,76 \\
\hline Permodalan & CAR & 15,51 & 17,93 & 15,22 & 14,92 & 14,65 \\
\hline \multicolumn{2}{|c|}{ Peringkat Komposit } & $\mathbf{2}$ & $\mathbf{2}$ & $\mathbf{2}$ & $\mathbf{2}$ & $\mathbf{2}$ \\
\hline \multicolumn{2}{|c|}{ Keterangan } & Sehat & Sehat & Sehat & Sehat & Sehat \\
\hline
\end{tabular}

Sumber: Data Diolah

Nilai rasio dari Bank Syariah BNI diatas menunjukkan predikat kesehatan tahun 2013 dari tujuh komponen yang dihitung, NPF, FDR, GCG, ROA, ROE, BOPO dan CAR hasilnya: 1,$74 ; 97,86 ; 3 ; 1,22 ; 11,69 ; 65,88$ dan 15,51 masuk kedalam komposit 2 yaitu sehat. Pada tahun 2014 nilai rasio, NPF, FDR, GCG, ROA, ROE, BOPO dan CAR hasilnya: 2,42; 92,60; 3; 1,13; 10,86; 55,25 dan 17,93 masuk kedalam komposit 2 yaitu sehat. Tahun 2015 nilai rasio, NPF, FDR, GCG, ROA, ROE, BOPO dan CAR sebesar: 1,01; 91,94; 3; 1,33;1 5,19; 49,12 dan 15,22 masuk komposit 2 sehat. Tahun 2016 NPF, FDR, GCG, ROA, ROE, BOPO dan CAR nilai rasio sebesar: 1,75; 90,84; 3; 1,32; 18,45; 48,09 dan 14,92 masuk komposit 2 sehat. Tahun 2017 NPF, FDR, GCG, ROA, ROE, BOPO dan CAR sebesar: 1,65; 91,02; 3; 1,29; 18,70; 47,76 dan 14,65 masuk kategori 2 sehat. Sesuai dengan standar yang telah ditetapkan oleh Bank Indonesia, pada tahun 2013-2017 Bank Syariah BNI dengan kesimpulan ada di peringkat komposit 2 yaitu sehat yang mencerminkan kondisi bank secara umum yaitu cukup sehat, sehingga dinilai mampu menghadapi pengaruh negatif yang signifikan dari perubahan kondisi bisnis dan juga faktor lainnya. 
ISLAMIC BANKING: Jurnal Pemikiran dan Pengembangan Perbankan Syariah, Volume 6 Nomor 1 Edisi Agustus 2020

4. PT Bank Syariah BRI

Tabel 6

Penilaian Tingkat Kesehatan Bank Syariah BRI Periode 2013-2017

\begin{tabular}{|c|l|c|c|c|c|c|}
\hline $\begin{array}{c}\text { Komponen } \\
\text { Faktor }\end{array}$ & \multirow{2}{*}{ Rasio } & \multicolumn{5}{|c|}{ \% Rasio } \\
\cline { 2 - 7 } Profil Risiko & NPF & 2013 & 2014 & 2015 & 2016 & 2017 \\
\cline { 2 - 7 } & FDR & $\begin{array}{c}102,7 \\
0\end{array}$ & 93,90 & 84,16 & 75,81 & 74,45 \\
\hline GCG & GCG & 3 & 3 & 3 & 3 & 3 \\
\hline \multirow{3}{*}{ Rentabilitas } & ROA & 1,05 & 0,07 & 0,70 & 0,86 & 0,83 \\
\cline { 2 - 7 } & ROE & 8,72 & 0,14 & 6,16 & 8,59 & 8,90 \\
\cline { 2 - 7 } & BOPO & 53,33 & 52,26 & 46,91 & 44,54 & 44,01 \\
\hline Permodalan & CAR & 14,05 & 12,50 & 13,92 & 14,93 & 15,56 \\
\hline Peringkat Komposit & $\mathbf{2}$ & $\mathbf{2}$ & $\mathbf{2}$ & $\mathbf{2}$ & $\mathbf{2}$ \\
\hline \multicolumn{2}{|c|}{ Keterangan } & Sehat & Sehat & Sehat & Sehat & Sehat \\
\hline
\end{tabular}

Sumber: Data Diolah

Nilai rasio dari Bank Syariah BRI diatas menunjukkan predikat kesehatan tahun 2013 dari tujuh komponen yang dihitung, NPF, FDR, GCG, ROA, ROE, BOPO dan CAR hasilnya: 2,33, 102,70; 3; 1,05; 8,72; 53,33 dan 14,05 masuk kedalam komposit 2 yaitu sehat. Pada tahun 2014 nilai rasio, NPF, FDR, GCG, ROA, ROE, BOPO dan CAR hasilnya: 1,$18 ; 93,90 ; 3 ; 0,07 ; 0,14,52,26$ dan 12,50 masuk kedalam komposit 2 yaitu sehat. Tahun 2015 nilai rasio, NPF, FDR, GCG, ROA, ROE, BOPO dan CAR sebesar: 2,23; 84,16; 3; 0,70; 6,16; 46,91 dan 13,92 masuk komposit 2 sehat. Tahun 2016 NPF, FDR, GCG, ROA, ROE, BOPO dan CAR nilai rasio sebesar: 3,22; 75,81; 3; 0,86; 8,59; 44,54 dan 14,93 masuk komposit 2 sehat. Tahun 2017 NPF, FDR, GCG, ROA, ROE, BOPO dan CAR sebesar: 2,78; 74,45; 3; 0,83; 8,90; 44,01 dan 15,56 masuk kategori 2 sehat. Sesuai dengan standar yang telah ditetapkan oleh Bank Indonesia, pada tahun 2013-2017 Bank Syariah BRI dengan kesimpulan ada di peringkat komposit 2 yaitu sehat yang mencerminkan kondisi bank secara umum yaitu cukup sehat, sehingga dinilai mampu menghadapi pengaruh negatif yang signifikan dari perubahan kondisi bisnis dan juga faktor lainnya. 
5. PT Bank Syariah Mega Indonesia

Tabel 7

Penilaian Tingkat Kesehatan Bank Syariah Mega Indonesia Periode 2013-2017

\begin{tabular}{|c|l|c|c|c|c|c|}
\hline \multirow{2}{*}{$\begin{array}{c}\text { Komponen } \\
\text { Faktor }\end{array}$} & \multirow{2}{*}{ Rasio } & \multicolumn{5}{|c|}{ \% Rasio } \\
\cline { 2 - 7 } Profil Risiko & NPF & 2013 & 2014 & 2015 & 2016 & 2017 \\
\cline { 2 - 7 } & FDR & 93,37 & 93,61 & 98,49 & 98,65 & 98,90 \\
\hline GCG & GCG & 3 & 3 & 3 & 3 & 3 \\
\hline \multirow{3}{*}{ Rentabilitas } & ROA & 0,95 & 1,00 & 1,81 & 1,90 & 1,67 \\
\cline { 2 - 7 } & ROE & 15,05 & 16,32 & 30,22 & 30,56 & 30,78 \\
\cline { 2 - 7 } & BOPO & 86,09 & 97,61 & 99,51 & 98,73 & 97,42 \\
\hline Permodalan & CAR & 12,99 & 19,26 & 18,74 & 18,83 & 18,05 \\
\hline \multicolumn{2}{|c|}{ Peringkat Komposit } & $\mathbf{2}$ & $\mathbf{2}$ & $\mathbf{2}$ & $\mathbf{2}$ & $\mathbf{2}$ \\
\hline \multicolumn{2}{|c|}{ Keterangan } & Sehat & Sehat & Sehat & Sehat & Sehat \\
\hline
\end{tabular}

Sumber: Data Diolah

Nilai rasio dari Bank Syariah Mega Indonesia diatas menunjukkan predikat kesehatan tahun 2013 dari tujuh komponen yang dihitung, NPF, FDR, GCG, ROA, ROE, BOPO dan CAR hasilnya: 0,00; 93,37; 3; 0,95; 15,05; 86,09 dan 12,99 masuk kedalam komposit 2 yaitu sehat. Pada tahun 2014 nilai rasio, NPF, FDR, GCG, ROA, ROE, BOPO dan CAR hasilnya: 4,29; 93,61; 3; 1,00; 16,32, 97,61 dan 19,26 masuk kedalam komposit 2 yaitu sehat. Tahun 2015 nilai rasio, NPF, FDR, GCG, ROA, ROE, BOPO dan CAR sebesar: 4,93; 98,49; 3; 1,81; 30,22; 99,51 dan 18,74 masuk komposit 2 sehat. Tahun 2016 NPF, FDR, GCG, ROA, ROE, BOPO dan CAR nilai rasio sebesar: 4,60; 98,65; 3; 1,90; 30,56; 98,73 dan 18,83 masuk komposit 2 sehat. Tahun 2017 NPF, FDR, GCG, ROA, ROE, BOPO dan CAR sebesar: 4,45; 98,90; 3; 1,67; 30,78; 97,42 dan 18,05 masuk kategori 2 sehat. Sesuai dengan standar yang telah ditetapkan oleh Bank Indonesia, pada tahun 2013-2017 Bank Syariah Mega Indonesia dengan kesimpulan ada di peringkat komposit 2 yaitu sehat yang mencerminkan kondisi bank secara umum yaitu cukup sehat, sehingga dinilai mampu menghadapi pengaruh negatif yang signifikan dari perubahan kondisi bisnis dan juga faktor lainnya.

6. PT Bank Jabar dan Banten Syariah

Tabel 8

Penilaian Tingkat Kesehatan Bank Jabar dan Banten Syariah Periode 20132017

\begin{tabular}{|c|l|c|c|c|c|c|}
\hline Komponen & \multirow{2}{*}{$\begin{array}{c}\text { Faktor } \\
\text { Fasio }\end{array}$} & \multicolumn{5}{|c|}{ \% Rasio } \\
\cline { 3 - 7 } & & 2013 & 2014 & 2015 & 2016 & 2017 \\
\hline Profil Risiko & NPF & 1,16 & 3,87 & 4,93 & 4,89 & 3,90 \\
\hline
\end{tabular}




\begin{tabular}{|c|l|c|c|c|c|c|}
\hline \multirow{2}{*}{$\begin{array}{c}\text { Komponen } \\
\text { Faktor }\end{array}$} & \multirow{2}{*}{ Rasio } & \multicolumn{5}{|c|}{ \% Rasio } \\
\cline { 2 - 7 } & FDR & 2013 & 2014 & 2015 & 2016 & 2017 \\
\hline \multirow{2}{*}{ GCG } & GCG & 3 & 3 & 3 & 3 & 3 \\
\hline \multirow{3}{*}{ Rentabilitas } & ROA & 0,64 & 0,72 & 1,26 & 1,45 & 1,89 \\
\cline { 2 - 7 } & ROE & 4,65 & 3,62 & 5,67 & 6,78 & 4,45 \\
\cline { 2 - 7 } & BOPO & 85,76 & 91,01 & 85,32 & 84,76 & 83,56 \\
\hline Permodalan & CAR & 17,99 & 15,78 & 18,74 & 16,83 & 13,05 \\
\hline Peringkat Komposit & $\mathbf{2}$ & $\mathbf{2}$ & $\mathbf{3}$ & $\mathbf{3}$ & $\mathbf{2}$ \\
\hline \multicolumn{2}{|c|}{ Keterangan } & Sehat & Sehat & $\begin{array}{c}\text { Cukup } \\
\text { Sehat }\end{array}$ & $\begin{array}{c}\text { Cukup } \\
\text { Sehat }\end{array}$ & Sehat \\
\hline
\end{tabular}

Sumber: Data Diolah

Nilai rasio dari Bank Jabar dan Banten Syariah diatas menunjukkan predikat kesehatan tahun 2013 dari tujuh komponen yang dihitung, NPF, FDR, GCG, ROA, ROE, BOPO dan CAR hasilnya: 1,16; 97,40; 3; 0,64; 4,65; 85,76 dan 17,99 masuk kedalam komposit 2 yaitu sehat. Pada tahun 2014 nilai rasio, NPF, FDR, GCG, ROA, ROE, BOPO dan CAR hasilnya: 3,87; 84,02; 3; 0,72; 3,62, 91,01 dan 15,78 masuk kedalam komposit 2 yaitu sehat. Tahun 2015 nilai rasio, NPF, FDR, GCG, ROA, ROE, BOPO dan CAR sebesar: 4,93; 83,58; 3; 1,26; 5,67; 85,32 dan 18,74 masuk komposit 3 Cukup Sehat. Tahun 2016 NPF, FDR, GCG, ROA, ROE, BOPO dan CAR nilai rasio sebesar: 4,89; 76,89; 3; 1,45; 6,78; 84,76 dan 16,83 masuk komposit 3 Cukup Sehat. Tahun 2017 NPF, FDR, GCG, ROA, ROE, BOPO dan CAR sebesar: 3,90; 79,63; 3; 1,$89 ; 4,45 ; 83,56$ dan 13,05 masuk kategori 2 sehat. Sesuai dengan standar yang telah ditetapkan oleh Bank Indonesia, pada tahun 2013-2017 Bank Jabar dan Banten Syariah dengan kesimpulan ada di peringkat komposit 2 yaitu Sehat yang mencerminkan kondisi bank secara umum yaitu cukup sehat, sehingga dinilai mampu menghadapi pengaruh negatif yang signifikan dari perubahan kondisi bisnis dan juga faktor lainnya.

7. PT Bank Panin Syariah

Tabel 9

Penilaian Tingkat Kesehatan Bank Panin Syariah Periode 2013-2017

\begin{tabular}{|c|l|c|c|c|c|c|}
\hline \multirow{2}{*}{$\begin{array}{c}\text { Komponen } \\
\text { Faktor }\end{array}$} & \multirow{2}{*}{ Rasio } & \multicolumn{5}{|c|}{ \% Rasio } \\
\cline { 3 - 7 } & & 2013 & 2014 & 2015 & 2016 & 2017 \\
\hline \multirow{2}{*}{$\begin{array}{c}\text { Profil Risiko } \\
\end{array}$} & NPF & 1,00 & 1,17 & 1,52 & 1,23 & 1,32 \\
\cline { 2 - 7 } & FDR & 90,40 & 94,04 & 96,43 & 93,27 & 91,64 \\
\hline GCG & GCG & 3 & 3 & 3 & 3 & 3 \\
\hline Rentabilitas & ROA & 1,98 & 2,13 & 1,34 & 1,76 & 1,56 \\
\hline
\end{tabular}


Hendra Galuh P, Amalia Indah F, MENILAI TINGKAT KESEHATAN BANK DENGAN............

\begin{tabular}{|c|l|c|c|c|c|c|}
\hline \multirow{3}{*}{$\begin{array}{c}\text { Komponen } \\
\text { Faktor }\end{array}$} & \multirow{2}{*}{ Rasio } & \multicolumn{5}{|c|}{ \% Rasio } \\
\cline { 2 - 7 } & & 2013 & 2014 & 2015 & 2016 & 2017 \\
\cline { 2 - 7 } & ROE & 101,91 & 107,68 & 65,07 & 50,76 & 64,67 \\
\cline { 2 - 7 } & BOPO & 81,31 & 82,58 & 89,29 & 86,89 & 87,56 \\
\hline Permodalan & CAR & 20,83 & 25,69 & 19,93 & 18,67 & 15,65 \\
\hline Peringkat Komposit & $\mathbf{2}$ & $\mathbf{2}$ & $\mathbf{2}$ & $\mathbf{2}$ & $\mathbf{2}$ \\
\hline \multicolumn{2}{|c|}{ Keterangan } & Sehat & Sehat & Sehat & Sehat & Sehat \\
\hline
\end{tabular}

Sumber: Data Diolah

Nilai rasio dari Bank Panin Syariah diatas menunjukkan predikat kesehatan tahun 2013 dari tujuh komponen yang dihitung, NPF, FDR, GCG, ROA, ROE, BOPO dan CAR hasilnya: 1,$00 ; 90,40 ; 3 ; 1,98 ; 101,91 ; 81,31$ dan 20,83 masuk kedalam komposit 2 yaitu sehat. Pada tahun 2014 nilai rasio, NPF, FDR, GCG, ROA, ROE, BOPO dan CAR hasilnya: 1,$17 ; 94,04 ; 3 ; 2,13 ; 107,68,82,58$ dan 25,69 masuk kedalam komposit 2 yaitu sehat. Tahun 2015 nilai rasio, NPF, FDR, GCG, ROA, ROE, BOPO dan CAR sebesar: 1,52; 96,43; 3; 1,34; 65,07; 89,29 dan 19,93 masuk komposit 2 Sehat. Tahun 2016 NPF, FDR, GCG, ROA, ROE, BOPO dan CAR nilai rasio sebesar: 1,23; 93,27; 3; 1,76; 50,76; 86,89 dan 18,67 masuk komposit 2 Sehat. Tahun 2017 NPF, FDR, GCG, ROA, ROE, BOPO dan CAR sebesar: 1,32; 91,64; 3; 1,56; 64,67; 87,56 dan 15,65 masuk kategori 2 sehat. Sesuai dengan standar yang telah ditetapkan oleh Bank Indonesia, pada tahun 2013-2017 Bank Panin Syariah dengan kesimpulan ada di peringkat komposit 2 yaitu Sehat yang mencerminkan kondisi bank secara umum yaitu cukup sehat, sehingga dinilai mampu menghadapi pengaruh negatif yang signifikan dari perubahan kondisi bisnis dan juga faktor lainnya.

8. PT Bank Syariah Bukopin

Tabel 10

Penilaian Tingkat Kesehatan Bank Syariah Bukopin Periode 2013-2017

\begin{tabular}{|c|l|c|c|c|c|c|}
\hline $\begin{array}{c}\text { Komponen } \\
\text { Faktor }\end{array}$ & \multirow{2}{*}{ Rasio } & \multicolumn{5}{|c|}{ \% Rasio } \\
\cline { 3 - 7 } Profil Risiko & NPF & 1,17 & 1,94 & 1,01 & 1,75 & 1,65 \\
\cline { 2 - 7 } & FDR & $\begin{array}{c}100,2 \\
9\end{array}$ & 92,89 & 90,56 & 88,18 & 85,65 \\
\hline GCG & GCG & 3 & 3 & 3 & 3 & 3 \\
\hline \multirow{3}{*}{ Rentabilitas } & ROA & 0,62 & 0,23 & 0,69 & 0,67 & 0,59 \\
\cline { 2 - 7 } & ROE & 4,22 & 1,23 & 3,60 & 3,76 & 4,67 \\
\cline { 2 - 7 } & BOPO & 57,39 & 58,63 & 64,31 & 91,76 & 84,37 \\
\hline Permodalan & CAR & 9,13 & 14,07 & 14,95 & 16,19 & 13,53 \\
\hline Peringkat Komposit & $\mathbf{2}$ & $\mathbf{2}$ & $\mathbf{3}$ & $\mathbf{2}$ & $\mathbf{2}$ \\
\hline
\end{tabular}




\begin{tabular}{|c|c|c|c|c|c|c|}
\hline \multirow{2}{*}{$\begin{array}{c}\text { Komponen } \\
\text { Faktor }\end{array}$} & \multirow{2}{*}{ Rasio } & \multicolumn{5}{|c|}{ \% Rasio } \\
\cline { 3 - 7 } & 2013 & 2014 & 2015 & 2016 & 2017 \\
\hline \multicolumn{2}{|c|}{ Keterangan } & Sehat & Sehat & $\begin{array}{c}\text { Cukup } \\
\text { Sehat }\end{array}$ & Sehat & Sehat \\
\hline
\end{tabular}

Sumber: Data Diolah

Nilai rasio dari Bank Syariah Bukopin diatas menunjukkan predikat kesehatan tahun 2013 dari tujuh komponen yang dihitung, NPF, FDR, GCG, ROA, ROE, BOPO dan CAR hasilnya: 1,17; 100,29; 3; 0,62; 4,22; 57,39 dan 9,13 masuk kedalam komposit 2 yaitu sehat. Pada tahun 2014 nilai rasio, NPF, FDR, GCG, ROA, ROE, BOPO dan CAR hasilnya: 1,$94 ; 92,89 ; 3 ; 0,23 ; 1,23,58,63$ dan 14,07 masuk kedalam komposit 2 yaitu sehat. Tahun 2015 nilai rasio, NPF, FDR, GCG, ROA, ROE, BOPO dan CAR sebesar: 1,01; 90,56; 3; 0,69; 3,60; 64,31 dan 14,95 masuk komposit 3 Cukup Sehat. Tahun 2016 NPF, FDR, GCG, ROA, ROE, BOPO dan CAR nilai rasio sebesar: 1,75; 88,18; 3; 0,67; 3,76; 91,76 dan 16,19 masuk komposit 2 Sehat. Tahun 2017 NPF, FDR, GCG, ROA, ROE, BOPO dan CAR sebesar: 1,65; 85,65; 3; 0,59; 4,67; 84,37 dan 13,53 masuk kategori 2 sehat. Sesuai dengan standar yang telah ditetapkan oleh Bank Indonesia, pada tahun 2013-2017 Bank Syariah Bukopin dengan kesimpulan ada di peringkat komposit 2 yaitu Sehat yang mencerminkan kondisi bank secara umum yaitu cukup sehat, sehingga dinilai mampu menghadapi pengaruh negatif yang signifikan dari perubahan kondisi bisnis dan juga faktor lainnya.

9. PT Bank Victoria Syariah

Tabel 11

Penilaian Tingkat Kesehatan Bank Victoria Syariah Periode 2013-2017

\begin{tabular}{|c|l|c|c|c|c|c|}
\hline \multirow{2}{*}{$\begin{array}{c}\text { Komponen } \\
\text { Faktor }\end{array}$} & \multirow{2}{*}{ Rasio } & \multicolumn{5}{|c|}{ \% Rasio } \\
\cline { 2 - 7 } Profil Risiko & NPF & 0,95 & 1,86 & 0,59 & 2,22 & 1,76 \\
\cline { 2 - 7 } & FDR & 84,65 & 95,19 & 95,29 & 100,67 & 96,63 \\
\hline GCG & GCG & 2 & 3 & 3 & 3 & 3 \\
\hline \multirow{3}{*}{ Rentabilitas } & ROA & 0,57 & 1,62 & 1,76 & $-1,72$ & 1,45 \\
\cline { 2 - 7 } & ROE & 3,70 & $-17,61$ & $-15,00$ & 8.80 & 4,67 \\
\cline { 2 - 7 } & BOPO & 92,00 & 35,2 & 62,90 & 23,80 & 53,06 \\
\hline Permodalan & CAR & 17,56 & 20,55 & 17,89 & 19,06 & 19,29 \\
\hline Peringkat Komposit & $\mathbf{3}$ & $\mathbf{3}$ & $\mathbf{3}$ & $\mathbf{3}$ & $\mathbf{3}$ \\
\hline \multicolumn{2}{|c|}{ Keterangan } & $\begin{array}{c}\text { Cukup } \\
\text { sehat }\end{array}$ & $\begin{array}{c}\text { Cukup } \\
\text { sehat }\end{array}$ & $\begin{array}{c}\text { Cukup } \\
\text { sehat }\end{array}$ & $\begin{array}{c}\text { Cukup } \\
\text { sehat }\end{array}$ & $\begin{array}{c}\text { Cukup } \\
\text { sehat }\end{array}$ \\
\hline
\end{tabular}

Sumber: Data Diolah 


\section{Hendra Galuh P, Amalia Indah F, MENILAI TINGKAT KESEHATAN BANK DeNGAN.............}

Nilai rasio dari Bank Victoria Syariah diatas menunjukkan predikat kesehatan tahun 2013 dari tujuh komponen yang dihitung, NPF, FDR, GCG, ROA, ROE, BOPO dan CAR hasilnya: 0,$95 ; 84,65 ; 2 ; 0,57 ; 3,70 ; 92,00$ dan 17,56 masuk kedalam komposit 3 yaitu Cukup Sehat. Pada tahun 2014 nilai rasio, NPF, FDR, GCG, ROA, ROE, BOPO dan CAR hasilnya: 1,86; 95,19; 3; 1,62; -17,61, 35,2 dan 20,55 masuk kedalam komposit 3 yaitu Cukup Sehat. Tahun 2015 nilai rasio, NPF, FDR, GCG, ROA, ROE, BOPO dan CAR sebesar: 0,59; 95,29; 3; 1,76; -15,00; 62,90 dan 17,89 masuk komposit 3 Cukup Sehat. Tahun 2016 NPF, FDR, GCG, ROA, ROE, BOPO dan CAR nilai rasio sebesar: 2,22; 100,67; 3; -1,72; 8,80; 23,80 dan 19,06 masuk komposit 3 Cukup Sehat. Tahun 2017 NPF, FDR, GCG, ROA, ROE, BOPO dan CAR sebesar: 1,76; 96,63; 3; 1,45; 4,67; 53,06 dan 19,29 masuk kategori 3 Cukup Sehat. Sesuai dengan standar yang telah ditetapkan oleh Bank Indonesia, pada tahun 2013-2017 Bank Victoria Syariah dengan kesimpulan ada di peringkat komposit 3 yaitu Cukup Sehat yang mencerminkan kondisi bank secara umum yaitu cukup sehat, sehingga dinilai mampu menghadapi pengaruh negatif yang signifikan dari perubahan kondisi bisnis dan juga faktor lainnya.

10. PT Maybank Indonesia Syariah

Tabel 12

Penilaian Tingkat Kesehatan Maybank Indonesia Syariah Periode 2013-2017

\begin{tabular}{|c|l|c|c|c|c|c|}
\hline \multirow{2}{*}{$\begin{array}{c}\text { Komponen } \\
\text { Faktor }\end{array}$} & \multirow{2}{*}{ Rasio } & \multicolumn{5}{|c|}{ \% Rasio } \\
\cline { 3 - 7 } Profil Risiko & NPF & 0,00 & 4,29 & 4,93 & 4,60 & 4,78 \\
\cline { 2 - 7 } & FDR & 152,87 & 157,77 & 110,54 & 134,72 & 121,56 \\
\hline GCG & GCG & 3 & 2 & 2 & 3 & 3 \\
\hline \multirow{3}{*}{ Rentabilitas } & ROA & 2,86 & 2,58 & $-22,43$ & $-10,71$ & 1,56 \\
\cline { 2 - 7 } & ROE & 5,05 & 6,83 & $-32,04$ & $-27,62$ & $-20,61$ \\
\cline { 2 - 7 } & BOPO & 67,79 & 69,62 & 192,60 & 160,28 & 97,78 \\
\hline Permodalan & CAR & 59,41 & 52,13 & 38,40 & 55,06 & 50,17 \\
\hline Peringkat Komposit & $\mathbf{3}$ & $\mathbf{3}$ & $\mathbf{3}$ & $\mathbf{3}$ & $\mathbf{3}$ \\
\hline \multicolumn{2}{|c}{ Keterangan } & $\begin{array}{c}\text { Cukup } \\
\text { Sehat }\end{array}$ & $\begin{array}{c}\text { Cukup } \\
\text { Sehat }\end{array}$ & $\begin{array}{c}\text { Cukup } \\
\text { Sehat }\end{array}$ & $\begin{array}{c}\text { Cukup } \\
\text { Sehat }\end{array}$ & $\begin{array}{c}\text { Cukup } \\
\text { Sehat }\end{array}$ \\
\hline
\end{tabular}

Sumber: Data Diolah

Nilai rasio dari Bank Maybank Indonesia Syariah diatas menunjukkan predikat kesehatan tahun 2013 dari tujuh komponen yang dihitung, NPF, FDR, GCG, ROA, ROE, BOPO dan CAR hasilnya: 0,00; 152,87; 3; 2,86; 5,05; 67,79 dan 59,41 masuk kedalam komposit 3 yaitu Cukup Sehat. Pada tahun 2014 nilai rasio, NPF, FDR, GCG, ROA, ROE, BOPO dan CAR hasilnya: 4,29; 157,77; 2; 2,58; 6,83, 69,62 dan 52,13 
masuk kedalam komposit 3 yaitu Cukup Sehat. Tahun 2015 nilai rasio, NPF, FDR, GCG, ROA, ROE, BOPO dan CAR sebesar: 4,93; 110,54; 2; -22,43; -32,04; 192,60 dan 38,40 masuk komposit 3 Cukup Sehat. Tahun 2016 NPF, FDR, GCG, ROA, ROE, BOPO dan CAR nilai rasio sebesar: 4,60; 134,72; 3; -10,71; -27,62; 160,28 dan 55,06 masuk komposit 3 Cukup Sehat. Tahun 2017 NPF, FDR, GCG, ROA, ROE, BOPO dan CAR sebesar: 4,78; 121,56; 3; 1,56; -20,61; 97,78 dan 50,17 masuk kategori 3 Cukup Sehat. Sesuai dengan standar yang telah ditetapkan oleh Bank Indonesia, pada tahun 2013-2017 Bank Maybank Indonesia Syariah dengan kesimpulan ada di peringkat komposit 3 yaitu Cukup Sehat yang mencerminkan kondisi bank secara umum yaitu cukup sehat, sehingga dinilai mampu menghadapi pengaruh negatif yang signifikan dari perubahan kondisi bisnis dan juga faktor lainnya.

\section{Rangkuman Hasil Penelitian dan Pembahasan}

Tabel 13

Rangkuman Hasil Peringkat Komposit

\begin{tabular}{|c|l|c|c|}
\hline NO & \multicolumn{1}{|c|}{ NAMA BANK } & $\begin{array}{c}\text { PERINGKAT } \\
\text { KOMPOSIT }\end{array}$ & KETERANGAN \\
\hline 1 & PT Bank Syariah Mandiri & 2 & SEHAT \\
\hline 2 & PT Bank Syariah Muamalat Indonesia & 2 & SEHAT \\
\hline 3 & PT Bank Syariah BNI & 2 & SEHAT \\
\hline 4 & PT Bank Syariah BRI & 2 & SEHAT \\
\hline 5 & PT Bank Syariah Mega Indonesia & 2 & SEHAT \\
\hline 6 & PT Bank Jabar dan Banten Syariah & 2 & SEHAT \\
\hline 7 & PT Bank Panin Syariah & 2 & SEHAT \\
\hline 8 & PT Bank Syariah Bukopin & 2 & SEHAT \\
\hline 9 & PT Bank Victoria Syariah & 3 & CUKUP SEHAT \\
\hline 10 & PT Maybank Indonesia Syariah. & 3 & CUKUP SEHAT \\
\hline
\end{tabular}

Penilaian Tingkat Kesehatan pada Bank Umum Syariah di Indonesia untuk periode 2013-2017 dengan menggunakan metode RGEC ini menunjukkan predikat kesehatan bank tersebut secara umum sesuai dengan standar yang telah ditetapkan oleh Bank Indonesia. Tingkat Kesehatan Bank ditinjau dari aspek Risk Profile, Good Corporate Governance, Earning and Capital pada sebelas Bank Umum Syariah di Indonesia selama periode 2013-2017 8 bank masuk kedalam peringkat komposit 2 yaitu "SEHAT" yang mencerminkan kondisi bank secara umum yaitu sehat, sehingga dinilai mampu menghadapi pengaruh negatif yang signifikan dari perubahan kondisi bisnis dan juga r-ISNIN . LUUU-YJYJ 


\section{Hendra Galuh P, Amalia Indah F, MENILAI TINGKAT KESEHATAN BANK DENGAN.............}

faktor lainnya. Sedangkan 2 bank masuk kedalam peringkat komposit 3 yaitu "CUKUP SEHAT'. Kedua bank tersebut yang harus menjadi pengawasan oleh Bank Indonesia (BI) supaya untuk ditingkatkan kembali kinerja perbankannya supaya tidak terjadinya penutupan bank karena banknya menjadi tidak sehat yang mencerminkan kondisi bank secara umum yaitu sehat, sehingga dinilai mampu menghadapi pengaruh negatif yang signifikan dari perubahan kondisi bisnis dan juga faktor lainnya.

\section{Simpulan}

Berdasarkan dari hasil penelitian dan analisis data yang telah disajikan sebelumnya mengenai "Analisis Penggunaan Metode Risk Profile, Good Corporate Governance, Earning, and Capital (RGEC) Dalam Mengukur Kesehatan Bank Pada Bank Syariah Di Indonesia Periode 2013-2017" dengan 10 Bank Syariah yang menjadi sampel dalam penelitian ini, maka dapat diambil kesimpulan yang berhubungan dengan penelitian ini. Secara umum kondisi kesehatan Perbank Syariah di Indonesia kurun waktu 2013-2017 berada di Peringkat Kompositnya 2 "SEHAT". Adapun bank-bank syariah yang dalam keadaan sehat yaitu: PT Bank Syariah Mandiri, PT Bank Syariah Muamalat Indonesia, PT Bank Syariah BNI, PT Bank Syariah BRI, PT Bank Syariah Mega Indonesia, PT Bank Jabar dan Banten Syariah, PT Bank Panin Syariah, PT Bank Syariah Bukopin. Sedangkan 2 Bank Syariah yaitu: PT Bank Victoria Syariah dan PT Maybank Indonesia Syariah peringkat komposit kesehatan perbankannya berada di nilai 3 "CUKUP SEHAT".

Saran-saran kepada Bank Umum Syariah di Indonesia terutama yang berkaitan dengan kesehatan bank, saran yang dapat penulis berikan kepada pihak Bank Umum Syariah di Indonesia yaitu sebagai berikut: 1) Mempertahankan kesehatan bank untuk tahun-tahun berikutnya tidak hanya berfokus pada laporan keuangan, tetapi Bank Umum Syariah di Indonesia perlu juga untuk mengembangkan usaha dengan pelayanan yang diberikan lebih aman, mudah, dan juga cepat. 2) Banyaknya faktor eksternal perusahaan yang berpengaruh terhadap kinerja keuangan seperti faktor pemerintahan sebaiknya juga lebih diperhatikan untuk meningkatkan kinerja keuangan. 3) Bagi peneliti selanjutnya, diharapkan memperpanjang periode penelitian sehingga dapat 
menilai bagaimana kesehatan bank dari periode sebelumnya, periode saat ini dan periode mendatang.

\section{DAFTAR PUSTAKA}

Aravik, H., Sulastyawati, D., \& Yunus, N. R. 2020. Leadership Concept At Sharia Bank; A Theoretical Study. Islamic Banking: Jurnal Pemikiran Dan Pengembangan Perbankan Syariah, 5(2), 21-32.

Fahmi, I. (2014). Manajemen Keuangan Perusahaan dan Pasar Modal. In Manajemen Keuangan Perusahaan dan Pasar Modal.

Fitriana, N., Rosyid, A., \& Fakhrina, A. (2015). Analisis Perbandingan Tingkat Kesehatan Bank Syariah Dan Konvensional Dengan Menggunakan Metode Rgec (Risk Profile , Good Corporate Governance , Earnings , Dan Capital). Jurnal Ekonomi Dan Bisnis, $\quad 17(2), \quad 1-12$. https://doi.org/http://dx.doi.org/10.31941/jebi.v17i2.332

Haris, H., \& Hastuti, N. S. (2013). Analisis Efisiensi Bank Umum Syariah Devisa Di Indonesia Dengan Metode Data Envelopment Analysis Studi Pada Bank Muamalat Indonesia Dan Bank Syariah Mandiri. Muqtasid: Jurnal Ekonomi Dan Perbankan Syariah. https://doi.org/10.18326/muqtasid.v4i1.1-25

http://infobanknews.com/perbankan-syariah-kinerja-yang-buruk-karena-tata-kelola/ (diakses tanggal 29 Juni 2019)

http://www.bnisyariah.co.id/ diakses 29 Juli 2019.

http://www.brisyariah.co.id/ diakses 29 Juli 2019

http://www.syariahmandiri.co.id/ diakses 29 Juli 2019

Kasmir. (2014a). Analisis Laporan Keuangan, Edisi Satu, Cetakan Ketujuh. In Raja Grafindo Persada.

Kasmir. (2014b). Bank dan Lembaga Kuangan Lainnya. In PT. Raja Grafindo Persada jakarta.

Otoritas Jasa Keuangan. (2017). Laporan Perkembangan Keuangan Syariah 2015. Jakarta.

Peraturan Otoritas Jasa Keuangan. 2014. Penilaian Tingkat Kesehatan Bank Umum Syariah

dan Unit Usaha Syariah. No 8/POJK.03/2014.

Rahmaniah, M., \& Wibowo, H. (2015). Analisis Potensi Terjadinya Financial Distress pada Bank Umum Syariah (BUS) di Indonesia. Jurnal Ekonomi Dan Perbankan Syariah.

Veithzal, R. and others. (2007). Bank and Financial Institute Management. Jakarta: PT. 
160 Hendra Galuh P, Amalia Indah F, MENILAI TINGKAT KESEHATAN BANK DeNGAN............. Raja Grafindo Persada.

Surat Edaran Bank Indonesia. (2011). Surat Edaran Bank Indonesia No. 13/24/DPNP tanggal

25 Oktober 2011. Tentang Matriks Perhitungan Analisis Komponen Faktor Analisis RGEC untuk Bank Umum.

Surat Edaran Otoritas Jasa Keuangan. (2014). SEOJK No. 10/SEOJK.03/2014. Tentang Penilaian Kesehatan Bank Umum Syariah dan Unit Usaha Syariah.

Surat Edaran Bank Indonesia. (2007). Surat Edaran Bank Indonesia No.9/24/DPbs Tanggal 30

Oktober 2011. Sistem Penilaian Tingkat Kesehatan Bank Umum Berdasarkan Prinsip

Syariah.

Surat Edaran Bank Indonesia. (2010). Surat Edaran Bank Indonesia No. 12/13/DPbs Tanggal

30 April 2010. Pelaksanaan Good Corporate Governance Bagi Bank Umum Syariah dan

Unit Usaha Syariah. 